\title{
Clinical Study \\ Prevalence of Occult Hepatitis C Virus in Egyptian Patients with Chronic Lymphoproliferative Disorders
}

\author{
Samar Samir Youssef,, ${ }^{1}$ Aml S. Nasr, ${ }^{2}$ Taher El Zanaty, ${ }^{3}$ \\ Rasha Sayed El Rawi, ${ }^{3}$ and Mervat M. Mattar ${ }^{3}$ \\ ${ }^{1}$ Microbial Biotechnology Department, National Research Centre, Cairo 12311, Egypt \\ ${ }^{2}$ Department of Clinical Pathology, Faculty of Medicine, Cairo University, Giza 12613, Egypt \\ ${ }^{3}$ Department of Internal Medicine, Faculty of Medicine, Cairo University, Giza 12613, Egypt
}

Correspondence should be addressed to Aml S. Nasr, amlsoliman78@yahoo.com

Received 30 August 2012; Revised 2 November 2012; Accepted 14 November 2012

Academic Editor: Piero Luigi Almasio

Copyright (c) 2012 Samar Samir Youssef et al. This is an open access article distributed under the Creative Commons Attribution License, which permits unrestricted use, distribution, and reproduction in any medium, provided the original work is properly cited.

\begin{abstract}
Background. Occult hepatitis C virus infection (OCI) was identified as a new form of Hepatitis C virus (HCV), characterized by undetectable HCV antibodies and HCV RNA in serum, while HCV RNA is detectable in liver and peripheral blood cells only. Aim. The aim of this study was to investigate the occurrence of OCI in Egyptian patients with lymphoproliferative disorders (LPDs) and to compare its prevalence with that of HCV in those patients. Subjects and Methods. The current study included 100 subjects, 50 of them were newly diagnosed cases having different lymphoproliferative disorders (patients group), and 50 were apparently healthy volunteers (controls group). HCV antibodies were detected by ELISA, HCV RNA was detected in serum and peripheral blood mononuclear cells (PBMCs) by reverse transcription polymerase chain reaction(RT-PCR), and HCV genotype was detected by INNO-LiPA. Results. OCI was detected in $20 \%$ of patients group, compared to only $4 \%$ OCI in controls group. HCV was detected in $26 \%$ of patients group with a slightly higher prevalence. There was a male predominance in both HCV and OCI. All HCV positive patients were genotype 4. Conclusion. Our data revealed occurrence of occult HCV infection in Egyptian LPD patients at a prevalence of $20 \%$ compared to $26 \%$ of $\mathrm{HCV}$.
\end{abstract}

\section{Introduction}

Chronic hepatitis C virus (HCV) infection remains a global health threat with 175 million carriers worldwide. Approximately $3 \%$ of the worldwide population is infected with the hepatitis $\mathrm{C}$ virus (HCV) [1]. The prevalence of $\mathrm{HCV}$ infection varies throughout the world, with the highest prevalence reported in Egypt [2]. HCV is an RNA virus that belongs to the family of flaviviruses [3]. The natural targets of HCV are hepatocytes and, possibly, B lymphocytes $[4,5]$.

A new form of chronic HCV infection named occult hepatitis $\mathrm{C}$ virus (OCI) was described by Castillo et al., 2004 [6]. This infection is characterized by absence of anti-HCV antibodies (Abs) and HCV RNA in serum with elevated liver function tests in the presence of HCV-RNA in the liver [6]. Furthermore, about $70 \%$ of patients with occult HCV infection also have HCV RNA in their peripheral blood mononuclear cells (PBMCs); the genomic and the antigenomic HCV RNA have also been detected in these cells [7]. Although detection of genomic HCV-RNA strand in liver biopsy specimen is the gold standard and the most accurate method for the diagnosis of occult HCV infection, testing for HCV-RNA in PBMCs is an alternative and easy to do when a liver biopsy is not available $[8,9]$.

Lymphoproliferative disorders is a term that includes a wide spectrum of pathologies ranging from a minor expansion of a B-cell population (with no clinical significance) to an aggressive high-grade lymphoma. Such proliferations of B cells apparently can be triggered as a consequence of a chronic antigenic stimulation resulting from an $\mathrm{HCV}$ infection [10]. Non-Hodgkin lymphoma (NHL) is the hematologic malignancy with the highest prevalence worldwide. Incidence rates have grown fast up to the beginning of the new millennium, with an annual percentage increase 
of nearly $3 \%$, which is faster than that for most cancers [11].

A causative association between hepatotropic viruses, especially hepatitis C virus, and malignant B-cell lymphoproliferative disorders has been demonstrated utilizing epidemiologic data, biologic and molecular investigations, as well as clinical observations. These data indicate that hepatitis $\mathrm{C}$ virus may be responsible for the development of some malignant lymphoproliferative disorders [11-17].

A former study on the malignant complications of chronic HCV infection in Egypt and association of HCV with increased risk of B-cell NHL as a whole was reported [18]. Recently, another study in Egypt proved that HCV is a risk factor for diffuse large B cell, marginal zone, and follicular lymphomas in Egypt [19]. Nonetheless, assessment of the existence of occult hepatitis C infection in LPD patients has not been addressed in Egypt and worldwide till now.

The objective of this study was to investigate the occurrence of occult Hepatitis $\mathrm{C}$ infection in lymphoproliferative disorders patients and to compare its prevalence with that of $\mathrm{HCV}$ in those patients.

\section{Subjects and Methods}

2.1. Subjects. All subjects included in the study were obtained from Clinical Hematology Unit of Internal Medicine Hospital at Kasr El-Eini School of medicine, Cairo University in the period between June 2010 and June 2011. Institutional ethical board approval was taken prior to the study, as well as informed consent was taken from all the participants. A total of 100 subjects were included in this study. Fifty of them were consecutive newly diagnosed LPD patients. Selection criteria for patients were to being confirm LPD patients, negative for infection with hepatitis B virus (HBV), HIV, Epstein-Barr virus (EBV), and cytomegalovirus (CMV). Out of the recruited 50 patients, there were 20 patients with non-Hodgkin lymphoma, 4 patients with Hodgkin disease, and 26 patients with chronic lymphocytic leukemia. The other 50 subjects were apparently healthy volunteers who were selected to be negative for HCV Ab and serum HCV RNA and to be age and sex matched with LPD patients recruited.

All the subjects included in the study were subjected for full history taking and clinical examination, complete blood picture $(\mathrm{CBC})$ with differential white cell count, complete liver and kidney functions, and HCV antibodies using the commercially available ELISA kits (Dia Sorin, Torino, Italy).

The patients group was subjected as well to beta 2 microglobulin, abdominal ultrasound for detection of organomegaly and lymphadenopathy, CT abdomen and pelvis for proper diagnosis and staging, immunophenotyping to role out chronic lymphocytic leukemia, lymph node biopsy for diagnosis of non-Hodgkin lymphoma and bone marrow biopsy, and immunohistochemistry for staging.

2.2. HCV Antibodies Detection and HCV Genotyping. Serum HCV antibodies were detected by ELISA (Dia Sorin, Torino,
Italy), while HCV genotyping was detected by INNO-LiPA HCV II (Bayer Health Care, Eragny, France).

2.3. RNA Extraction from Serum and PBMC. RNA was extracted from serum and PBMC using Biozol (Bioflux, China, Catalogue no. BSJ000210001 M80) total RNA extraction reagent according to the manufacturer's protocol.

2.4. Detection of the HCV RNA Plus Strand. HCV RNA plus strand was determined by reverse transcription-polymerase chain reaction (RT-PCR). RNA was reverse-transcribed and amplified by One Step RT-PCR QIAGEN Kit (Catalogue no. 210212, sensitivity 22 viral copies) with appropriate primers (5'-CGC GCG ACT AGG AAG ACT TC- $3^{\prime}$ ) and (5'-ATA GAG AAA GAG CAAC CA GG-3') as forward and reverse primers, respectively. The lack of contamination in PCR reactions and was assessed by the inclusion of a negative control containing water rather than RNA in each assay which did not show any PCR amplification in all experiments. Moreover, each sample was done in duplicate to ensure absence of false positive results. Thermal cycling conditions were denaturation: for $1 \mathrm{~min}$ at $94^{\circ} \mathrm{C}$, annealing: for $1 \mathrm{~min}$ at $55^{\circ} \mathrm{C}$, extension: for $1 \mathrm{~min}$ at $72^{\circ} \mathrm{C}$ for 30 cycles, and final extension for $10 \mathrm{~min}$ at $72^{\circ} \mathrm{C}$. The PCR product (174 bp) was submitted to electrophoresis by using a 1.5 agarose gel and was visualized by ethidium bromide staining under ultraviolet light.

2.5. Detection of the HCV Minus Strand in LPD Patients with OCI. HCV RNA minus strand was determined by a previously established and described in house RT-PCR assay [20]. Reverse transcription was performed in $25 \mu \mathrm{L}$ reaction mixture containing $20 \mathrm{U}$ of AMV reverse transcriptase (Clontech, USA) with $400 \mathrm{ng}(3 \mu \mathrm{L})$ of total PBMCs RNA, $40 \mathrm{U}$ of RNasin (Clontech, USA), $0.2 \mathrm{mmol} / \mathrm{L}$ from each dNTP (Promega, Madison, WI, USA), and $50 \mathrm{pmol}$ of the forward primer $2 \mathrm{CH}$ (for minus strand). The reverse transcription reaction was performed at $42^{\circ} \mathrm{C}$ for one hour. Amplification of the highly conserved $5^{\prime}$-UTR sequences was done using two PCR rounds with two pairs of nested primers. First round amplification was done in $50 \mu \mathrm{L}$ reaction mixture, containing $50 \mathrm{pmol}$ from each of $2 \mathrm{CH}\left(5^{\prime}-\right.$ AAC TAC TGT CTT CAC GCA GAA- $3^{\prime}$ ) forward primer and P2 (5'-TGC TCA TGG TGC ACG GTC TA- $\left.3^{\prime}\right)$ reverse primer, $0.2 \mathrm{mmol} / \mathrm{L}$ from each dNTP, $10 \mu \mathrm{L}$ from RT reaction mixture as template, and $2 \mathrm{U}$ of Taq DNA polymerase (Promega, USA) in a 1x buffer supplied with the enzyme. A positive control RNA of an HCV patient previously tested and confirmed to harbor that only the negative strand was included. Moreover, two types of negative controls were included, a negative RT control having no RNA at the reverse transcription step and a PCR negative control having water instead of cDNA. The thermal cycling profile was $1 \mathrm{~min}$ at $94^{\circ} \mathrm{C}, 1 \mathrm{~min}$ at $55^{\circ} \mathrm{C}$, and $1 \mathrm{~min}$ at $72^{\circ} \mathrm{C}$ for 30 cycles. The second round amplification was done similar to the first round, except for use of the nested reverse primer D2 (5'-ACT CGG CTA GCA GTC TCG CG- $3^{\prime}$ ) and forward primer F2 (5'-GTGCAGCCTCCAGGACCC- $\left.3^{\prime}\right)$ at $50 \mathrm{pmol}$ 
TABle 1: Demographic and clinical data of patients and controls groups.

\begin{tabular}{|c|c|c|c|c|c|}
\hline & \multicolumn{2}{|c|}{ Patients $(N) \%$} & \multicolumn{2}{|c|}{ Controls $(N) \%$} & $P$ value \\
\hline \multicolumn{6}{|l|}{ Sex } \\
\hline Female & \multicolumn{2}{|c|}{$24(48 \%)$} & \multicolumn{2}{|c|}{$14(28 \%)$} & $00627 *$ \\
\hline Male & \multicolumn{2}{|c|}{$26(52 \%)$} & \multicolumn{2}{|c|}{$36(72 \%)$} & $0.063 / x$ \\
\hline Hepatomegaly & \multicolumn{2}{|c|}{$25(50 \%)$} & \multicolumn{2}{|c|}{$4(3 \%)$} & $<0.0001^{* * *}$ \\
\hline Splenomegaly & \multicolumn{2}{|c|}{$42(84 \%)$} & \multicolumn{2}{|c|}{$4(3 \%)$} & $<0.0001^{* * *}$ \\
\hline Lymphadenopathy & \multicolumn{2}{|c|}{$27(54 \%)$} & \multicolumn{2}{|c|}{$2(1 \%)$} & $<0.0001^{* * *}$ \\
\hline \multirow{2}{*}{ Age (years) } & Range & Mean \pm SD & Range & Mean \pm SD & \\
\hline & $18-68$ & $45.8 \pm 12.7$ & $20-63$ & $38.2 \pm 11.8$ & $0.25^{*}$ \\
\hline
\end{tabular}

$N$ : number of subjects. ${ }^{*}$ Not significant $(\mathrm{NS})(P$ value $>0.05),{ }^{* *}$ significant $(\mathrm{S})(P$ value $<0.05),{ }^{* * *}$ highly significant $(\mathrm{HS})(P$ value $<0.0001)$.

TABLE 2: Laboratory data of patients and controls groups.

\begin{tabular}{|c|c|c|c|c|c|}
\hline & \multicolumn{2}{|c|}{ Patients $(N=50)$} & \multicolumn{2}{|c|}{ Controls $(N=50)$} & \multirow{2}{*}{$P$ value } \\
\hline & Range & Mean \pm SD & Range & Mean \pm SD & \\
\hline Hemoglobin (gm\%) & $6.5-16$ & $10.6 \pm 2.5$ & $11.4-16$ & $13.3 \pm 1.4$ & $<0.0001^{* * *}$ \\
\hline Platelet count $\times 10^{3} \mathrm{~mm}^{3}$ & $21-567$ & $172.7 \pm 104.8$ & $168-394$ & $282.5 \pm 63.5$ & $<0.0001^{* * *}$ \\
\hline Total leucocytic count $/ \mathrm{mm}^{3}$ & $1.2-33$ & $8.6 \pm 5.6$ & $6-15$ & $10.0 \pm 2.4$ & $0.1074^{*}$ \\
\hline $\operatorname{AST}(\mathrm{IU} / \mathrm{dL})$ & $11-192$ & $41.9 \pm 38.0$ & $10-38$ & $15.7 \pm 2.1$ & $<0.0001^{* * *}$ \\
\hline $\operatorname{ALT}(\mathrm{IU} / \mathrm{dL})$ & $7-133$ & $34.1 \pm 29.9$ & $12-48$ & $18 \pm 3.4$ & $<0.0001^{* * *}$ \\
\hline Bilirubin (mg/dL) & $0.10-2.80$ & $0.75 \pm 0.64$ & $0.1-1.1$ & $0.8 \pm 0.2$ & $0.5992^{*}$ \\
\hline
\end{tabular}

$N$ : number of subjects. $*$ Not significant $(\mathrm{NS})(P$ value $>0.05),{ }^{*}$ significant $(\mathrm{S})(P$ value $<0.05), * * *$ highly significant $(\mathrm{HS})(P$ value $<0.0001)$.

each. PCR (179 bp) products were analyzed on $2 \%$ agarose gel electrolysis.

\section{Statistics}

Statistical calculations were performed using Microsoft Excel version 7 (Microsoft Corp., Redmond, WA, USA) and SPSS for Windows version 16 (SPSS Inc., Chicago, IL, USA) software.

Results were reported as mean \pm standard deviation $( \pm \mathrm{SD})$ or frequency $(\%)$ when appropriate. Comparison of quantitative variables between the study groups was done using one-way analysis of variance test. Correlation between various variables was done using Pearson moment correlation equation for linear relation. Correlation was considered large if between 1.0 and 0.5 , medium if between 0.5 and 0.3 , weak if between 0.3 and 0.1 , and no correlation if between 0.1 and $0.0 . P$ value less than 0.05 was considered statistically significant and less than 0.01 was considered statistically highly significant.

\section{Results}

4.1. Demographic, Clinical, and Laboratory Results. The demographic and clinical data of the LPD patients group are summarized in Table 1, also there were no statistically significant differences between the 2 groups regarding sex $(P=0.0639)$ and age $(P=0.25)$. There were highly statistically significant differences between the 2 groups regarding hepatomegaly, splenomegaly, and lymphadenopathy $(P<$ $0.0001)$. The laboratory data of the patients and control are shown in Table 2. The laboratory data of the patients and controls are shown in Table 2, and high statistical significance differences were seen between the 2 studied groups in haemoglobin, platelet count, AST, and ALT $(P<0.0001)$.

4.2. Results of HCV Ab and Plus and Minus HCV Strands Detection. In LPD patients, HCV Ab was detected in 13 out of $50(26 \%)$ patients, and serum HCV RNA detection results were identical to $\mathrm{HCV}$ Ab positivity, so 13 out of $50(26 \%)$ patients were positive. PBMC HCV plus strand was detected in 18 out of 50 (36\%) LPD patients (Figure 1), and among these, ten $(20 \%)$ patients were negative for $\mathrm{HCV}$ $\mathrm{Ab}$ and serum HCV RNA representing OCI patients. PBMC HCV minus strand was checked in the ten OCI positive LPD patients only and was undetectable in all of them. In controls group PBMC HCV plus strand was detected in only 2 out of 50 cases (4\%) representing OCI prevalence in this group. Statistical analysis showed significant differences between patients and controls regarding the incidence of occult HCV ( $P=0.0001)$, suggesting that occult $\mathrm{HCV}$ is associated with NHL and can be considered as a risk factor for NHL. RT$\mathrm{PCR}$ results for the detection of HCV minus strand in PBMC of OCI positive patients were all negative.

4.3. HCV Genotyping Results. HCV genotyping results showed that all HCV and OCI positive patients were genotype 4.

4.4. Correlation of Clinical and Laboratory Data of HCV Positive LPD Patients, OCI Positive LPD Patients, and HCV Negative OCI Negative LPD Patients Groups. As shown in 


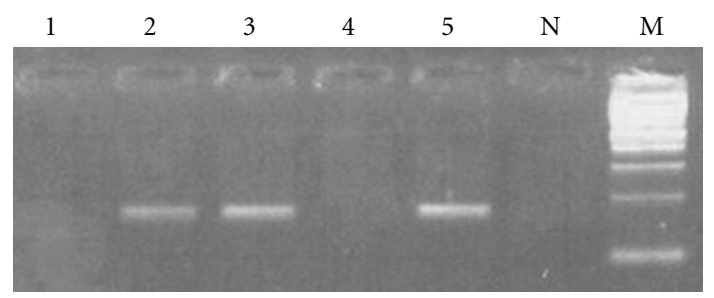

FIGURE 1: Results of PCR amplification of HCV plus RNA strand in PBMC. PCR products of amplification of HCV plus strand from PBMCs of LPD patients (lanes 1, 2, 3, and 4). Lane N represents the negative control of the PCR. Lane 5 is the positive control of the PCR. Lane M is $100 \mathrm{Bp}$ Mwt marker.

TABLE 3: Correlation between clinical and laboratory data in HCV positive and OCI positive LPD patients versus HCV and OCI negative LPD patients.

\begin{tabular}{|c|c|c|c|c|c|c|}
\hline \multirow{3}{*}{ Parameter } & \multicolumn{6}{|c|}{ LPD patients } \\
\hline & \multicolumn{2}{|c|}{ HCV positive } & \multicolumn{2}{|c|}{ OCI positive } & \multicolumn{2}{|c|}{$\mathrm{HCV}$ and $\mathrm{OCI}$ negative } \\
\hline & $r$ & $P$ value & $r$ & $P$ value & $r$ & $P$ value \\
\hline Age & 0.091 & 0.528 & 0.082 & 0.571 & 0.018 & 0.9 \\
\hline Hepatomegaly & 0.060 & 0.267 & 0.063 & 0.257 & 0.161 & 0.244 \\
\hline Splenomegaly & 0.092 & 0.526 & 0.089 & 0.538 & 0.095 & 0.514 \\
\hline Sex & 0.022 & 0.399 & 0.096 & 0.172 & 0.0171 & 0.234 \\
\hline $\mathrm{Hb}(\mathrm{gm} \%)$ & 0.323 & 0.037 & 0.086 & 0.552 & 0.092 & 0.525 \\
\hline Platelets $\times 10^{3} \mathrm{~mm}^{3}$ & 0.437 & 0.040 & 0.316 & 0.013 & 0.065 & 0.653 \\
\hline $\mathrm{TLC} / \mathrm{mm}^{3}$ & 0.074 & 0.608 & 0.018 & 0.413 & 0.000 & 0.999 \\
\hline AST & 0.022 & 0.398 & 0.446 & 0.053 & 0.048 & 0.742 \\
\hline ALT & 0.221 & 0.044 & 0.029 & 0.110 & 0.250 & 0.08 \\
\hline Bilirubin (T) & 0.059 & 0.682 & 0.518 & 0.021 & 0.236 & 0.098 \\
\hline
\end{tabular}

Table 3, according to Pearson correlation, there were no correlations between age, hepatosplenomegaly, sex, TLC, AST, and total bilirubin, while there was positive correlation between $\mathrm{Hb}$, platelet count, ALT, and positive HCV antibodies LPD patients. In OCI positive LPD patients, there were no correlations between age, hepatosplenomegaly, sex, $\mathrm{Hb}$, TLC, and ALT, while there was positive correlation between platelet count, AST, total bilirubin, and OCI positive patients. In HCV negative OCI negative LPD patients groups, there was no statistically significant correlation with age, hepatosplenomegaly, sex, TLC, AST, Hb, platelet count, ALT, and total bilirubin. In both HCV positive and OCI positive patients, number of male patients exceeded that of female patients. Among ten OCI positive patients, six were males, while nine of thirteen $\mathrm{HCV}$ patients were males.

4.5. Results of Association between Blood Transfusion and $\mathrm{HCV}$ Positivity. In order to identify the association between blood transfusion and HCV positivity in LPD patients, we identified the total number of patients subjected to blood transfusion. Out of 50 LPD patients, 16 patients received blood transfusion including 5 anti-HCV positive LPD patients, 5 OCI positive LPD patients, and $6 \mathrm{LPD}$ patients negative or anti-HCV and OCI. Subsequently, statistical analysis was used to assess this association (Table 4). There was statistically significant difference between the total number of HCV (HCV + OCI) positive LPD and non-HCV positive LPD patients and the blood transfusion, proving positive role of blood transfusion in LPD patients having $\mathrm{HCV}$ over those without HCV.

\section{Discussion}

Multiple reports have described an association between chronic HCV infection and B-cell NHL [21]. One of those concluded that the prevalence of $\mathrm{HCV}$ infection in patients with B-cell NHL was 15\% much greater than in the general population [22]. In Egyptian population, this association was also proved by Goldman et al., 2009 [23].

Occult HCV infection (OCI) is a new entity of HCV. Authors have long struggled to prove the existence of occult hepatitis $\mathrm{C}$ infection (OCI). Recently, it has been documented in haemodialysis patients, in chronic HCV patients after SVR, in general populations, and in chronic liver disease patients of unknown etiology [24-28]; nonetheless, it have never been studied in LPD patients. In Egypt, a recent study have shown high incidence of OCI in nonalcoholic liver disease (40.7\%) [29]. To the best of our knowledge, this study is considered the first to investigate the detection of OCI in LPD patients.

Surprisingly, our results showed the detection of OCI in $20 \%$ of NHL patients compared to $4 \%$ OCI only in control healthy volunteers. Statistical analysis of the differential existence of OCI in LPD patients versus healthy controls showed a highly significant $P$ value equal to 0.0312 , 
TABLE 4: Comparison of different patients group regarding blood transfusion.

\begin{tabular}{lccccr}
\hline & \multicolumn{3}{c}{ Blood transfusion } & & \\
HCV, not occult = +ve (abs \& PCR) & Occult HCV & $P$ value & Total HCV & Total non-HCV & $P$ value \\
\hline$(31.25 \%) 5 / 16$ & $(31.25 \%) 5 / 16$ & 0.987 & $(62.5 \%) 10 / 16$ & $(37.5 \%) 6 / 16$ & 0.0214 \\
\hline
\end{tabular}

confirming association of OCI with LPD and suggesting its incrimination in lymphomagenesis. It should be noted that detecting OCI by testing HCV RNA in PBMC is an alternative method when liver biopsy is not available, and that OCI is detected in PBMC of $70 \%$ only of patients with OCI. Therefore, it should be expected that the prevalence of OCI in LPD patients might exceed that reported in this study if detected in liver biopsies.

In this study, $4 \%$ of control healthy volunteers were OCI positive, which is the first record for the prevalence of OCI in healthy individuals in Egypt. This is consistent with that recorded by De Marco et al., 2009 [25], which showed evidence that occult HCV infection may occur in 3.3\% of population unselected for hepatic disease.

In the present study, the patients selection criteria were to be newly diagnosed LPD patient and was blind regarding positivity for HCV antibodies (Abs)s in order to compare the prevalence of HCV with that of OCI blindly. Results showed $\mathrm{HCV}$ prevalence of $26 \%$, which is slightly higher than OCI (20\%). Consequently, the total burden of HCV in LPD patients calculated based on the existence of $\mathrm{HCV}$ only versus existence of both OCI and HCV was raised from $26 \%$ to $52 \%$, respectively.

The HCV genotype detected in LPD patients positive for either HCV or OCI was genotype 4. This is consistent with previous studies reporting predominance of this genotype in Egypt [30].

Previous studies indicated that 22-66 years is the common age of OCI. Our results agreed with that. Moreover, in our study, OCI was detected in a young male patient 18 years old, reflecting its occurrence in such young age. This, together with the fact that male sex is predominant in OCI is accordant with previous studies by [7] and [31].

Saad et al. [29] reported that occult HCV infection seems to induce a mild liver disease, and Followup is recommended for the occult $\mathrm{HCV}$ patients to monitor progression to overt disease. Accordingly, it should be taken into consideration that NHL patients with elevated liver function tests with unknown etiology should be tested for OCI and should be carefully followed up.

Blood transfusion was examined as a risk factor for occurrence of HCV and OCI in LPD patients. As shown in the Results section, statistical analysis of its role in LPD $\mathrm{HCV} \mathrm{Ab}$ positive patients alone was not significant and similarly for LPD OCI alone was not significant. Nonetheless a significant correlation was recorded when calculation was based on the total HCV plus OCI, raising the inevitable role of OCI in studying this risk factor. On the other hand, it should be noted that OCI positive NHL patients who did not receive blood transfusion are equal in number with those who received it, indicating that there are two accepted probabilities, either HCV and OCI can be acquired in LPD patients as a consequence of blood transfusion of infected blood, or LPD may arise as a disorder due to HCV infection.

In conclusion, the present study, although having relatively low number of patients, is the first to demonstrate the occurrence of OCI in LPD patients in Egypt and worldwide and to highlight the fact that the burden of HCV in LPD is doubled if OCI is considered. Further studies with larger sample are recommended in order to assess the impact of OCI on LPD progression.

\section{References}

[1] WHO, "Hepatitis C-global prevalence (update)," The Weekly Epidemiological Record, vol. 74, pp. 425-427, 1999.

[2] C. Frank, M. K. Mohamed, G. T. Strickland et al., "The role of parenteral antischistosomal therapy in the spread of hepatitis C virus in Egypt," Lancet, vol. 355, no. 9207, pp. 887-891, 2000.

[3] B. Robertson, G. Myers, C. Howard et al., "Classification, nomenclature, and database development for hepatitis $\mathrm{C}$ virus (HCV) and related viruses: proposals for standardization," Archives of Virology, vol. 143, no. 12, pp. 2493-2503, 1998.

[4] M. Okuda, K. Hino, M. Korenaga, Y. Yamaguchi, Y. Katoh, and K. Okita, "Differences in hypervariable region 1 quasispecies of hepatitis C virus in human serum, peripheral blood mononuclear cells, and liver," Hepatology, vol. 29, no. 1, pp. 217-222, 1999.

[5] A. L. Zignego, M. De Carli, M. Monti et al., "Hepatitis C virus infection of mononuclear cells from peripheral blood and liver infiltrates in chronically infected patients," Journal of Medical Virology, vol. 47, no. 1, pp. 58-64, 1995.

[6] I. Castillo, M. Pardo, J. Bartolomé et al., "Occult hepatitis C virus infection in patients in whom the etiology of persistently abnormal results of liver-function tests is unknow," Journal of Infectious Diseases, vol. 189, no. 1, pp. 7-14, 2004.

[7] J. M. López-Alcorocho, E. Rodríguez-Iñigo, I. Castillo et al., "The role of genomic and antigenomic HCV-RNA strands as predictive factors of response to pegylated interferon plus ribavirin therapy," Alimentary Pharmacology and Therapeutics, vol. 25, no. 10, pp. 1193-1201, 2007.

[8] G. Barril, I. Castillo, M. D. Arenas et al., "Occult hepatitis C virus infection among hemodialysis patients," Journal of the American Society of Nephrology, vol. 19, no. 12, pp. 2288-2292, 2008.

[9] F. Franzin, D. G. Efremov, G. Pozzato, P. Tulissi, F. Batista, and O. R. Burrone, "Clonal B-cell expansions in peripheral blood of HCV-infected patients," British Journal of Haematology, vol. 90, no. 3, pp. 548-552, 1995.

[10] F. Marcucci and A. Mele, "Hepatitis viruses and non-Hodgkin lymphoma: epidemiology, mechanisms of tumorigenesis, and therapeutic opportunities," Blood, vol. 117, no. 6, pp. 17921798, 2011.

[11] S. C. Gordon, "Extrahepatic manifestations of hepatitis C," Digestive Diseases, vol. 14, no. 3, pp. 157-168, 1996. 
[12] R. Idilman, A. Colantoni, N. De Maria, S. Alkan, S. Nand, and D. H. Van Thiel, "Lymphoproliferative disorders in chronic hepatitis C," Journal of Viral Hepatitis, vol. 11, no. 4, pp. 302309, 2004.

[13] L. Dal Maso and S. Franceschi, "Hepatitis C virus and risk of lymphoma and other lymphoid neoplasms: a meta-analysis of epidemiologic studies," Cancer Epidemiology Biomarkers and Prevention, vol. 15, no. 11, pp. 2078-2085, 2006.

[14] A. Nieters, B. Kallinowski, P. Brennan et al., "Hepatitis C and risk of lymphoma: results of the European multicenter casecontrol study EPILYMPH," Gastroenterology, vol. 131, no. 6, pp. 1879-1886, 2006.

[15] A. L. Zignego, C. Giannini, M. Monti, and L. Gragnani, "Hepatitis C virus lymphotropism: lessons from a decade of studies," Digestive and Liver Disease, vol. 39, supplement 1, pp. S38-S45, 2007.

[16] M. H. Chen, L. T. Hsiao, T. J. Chiou et al., "High prevalence of occult hepatitis B virus infection in patients with B cell nonHodgkin's lymphoma," Annals of Hematology, vol. 87, no. 6, pp. 475-480, 2008.

[17] G. M. El-Sayed, W. S. Mohamed, M. A. Nouh, M. M. Moneer, and H. A. El-Mahallawy, "Viral genomes and antigen detection of hepatitis B and C viruses in involved lymph nodes of Egyptian non-Hodgkin's lymphoma patients," The Egyptian Journal of Immunology, vol. 13, no. 1, pp. 105-114, 2006.

[18] L. Goldman, S. Ezzat, N. Mokhtar et al., "Viral and nonviral risk factors for non-Hodgkin's lymphoma in Egypt: heterogeneity by histological and immunological subtypes," Cancer Causes and Control, vol. 20, no. 6, pp. 981-987, 2009.

[19] I. Gouda, O. Nada, S. Ezzat et al., "Immunohistochemical detection of hepatitis C virus (genotype 4) in B-cell NHL in an Egyptian population: correlation with serum HCV-RNA," Applied Immunohistochemistry and Molecular Morphology, vol. 18, no. 1, pp. 29-34, 2010.

[20] M. K. El-Awady, S. S. Youssef, M. H. Omran, A. A. Tabll, W. T. El Garf, and A. M. Salem, "Soluble egg antigen of Schistosoma Haematobium induces HCV replication in PBMC from patients with chronic HCV infection," BMC Infectious Diseases, vol. 6, article no. 91, 2006.

[21] R. Idilman, Y. Bozkus, G. Seval et al., "Lymphoproliferative disorders in individuals with chronic hepatitis b and $\mathrm{C}$ in the Turkish population," Journal of Medical Virology, vol. 83, no. 6, pp. 974-980, 2011.

[22] T. N. Q. Pham, C. S. Coffin, and T. I. Michalak, "Occult hepatitis C virus infection: what does it mean?" Liver International, vol. 30, no. 4, pp. 502-511, 2010.

[23] L. Goldman, S. Ezzat, N. Mokhtar et al., "Viral and nonviral risk factors for non-Hodgkin's lymphoma in Egypt: heterogeneity by histological and immunological subtypes," Cancer Causes and Control, vol. 20, no. 6, pp. 981-987, 2009.

[24] H. Zaghloul and W. El-Sherbiny, "Detection of occult hepatitis $\mathrm{C}$ and hepatitis B virus infections from peripheral blood mononuclear cells," Immunological Investigations, vol. 39, no. 3, pp. 284-291, 2010.

[25] L. De Marco, A. Gillio-Tos, V. Fiano et al., "Occult HCV infection: an unexpected finding in a population unselected for hepatic disease," PloS One, vol. 4, no. 12, article no. e8128, 2009.

[26] T. N. Q. Pham, S. E. Mercer, and T. I. Michalak, "Chronic hepatitis $\mathrm{C}$ and persistent occult hepatitis $\mathrm{C}$ virus infection are characterized by distinct immune cell cytokine expression profiles," Journal of Viral Hepatitis, vol. 16, no. 8, pp. 547-556, 2009.
[27] Y. Kondo, V. M. H. Sung, K. Machida, M. Liu, and M. M. C. Lai, "Hepatitis $\mathrm{C}$ virus infects $\mathrm{T}$ cells and affects interferon- $\gamma$ signaling in T cell lines," Virology, vol. 361, no. 1, pp. 161-173, 2007.

[28] F. Bokharaei-Salim, H. Keyvani, S. H. R. Monavari et al., "Occult hepatitis C virus infection in Iranian patients with cryptogenic liver disease," Journal of Medical Virology, vol. 83, no. 6, pp. 989-995, 2011.

[29] Y. Saad, S. Zakaria, I. Ramzy et al., "Prevalence of occult hepatitis $\mathrm{C}$ in Egyptian patients with non alcoholic fatty liver disease," Open Journal of Internal Medicine, vol. 1, pp. 33-37, 2011.

[30] S. C. Ray, R. R. Arthur, A. Carella, J. Bukh, and D. L. Thomas, "Genetic epidemiology of hepatitis C virus throughout Egypt," Journal of Infectious Diseases, vol. 182, no. 3, pp. 698-707, 2000.

[31] I. Castillo, E. Rodríguez-Iñigo, J. M. López-Alcorocho, J. Bartolomé, M. Pardo, and V. Carreño, "Comparative study on the clinical and virological characteristics among patients with single occult hepatitis B virus (HBV), single occult hepatitis $\mathrm{C}$ virus (HCV) and occult HBV and HCV dual infection," Journal of Medical Virology, vol. 79, no. 3, pp. 236-241, 2007. 


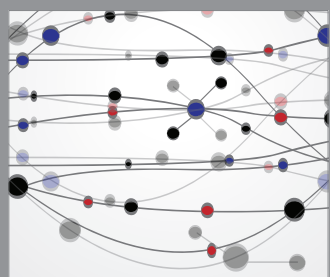

The Scientific World Journal
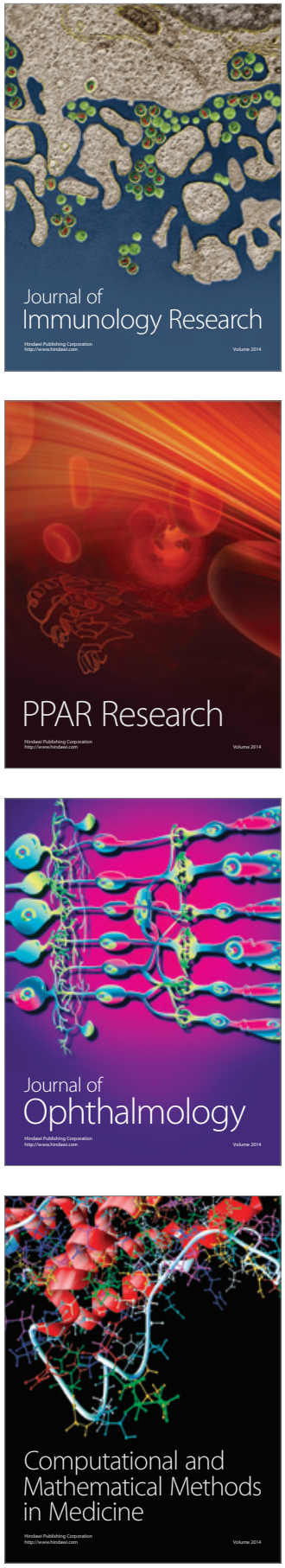

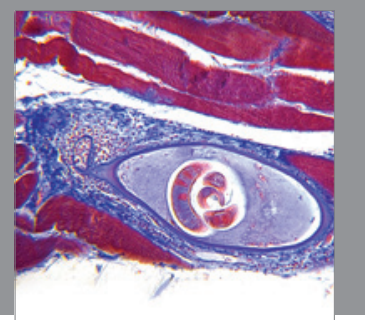

Gastroenterology

Research and Practice
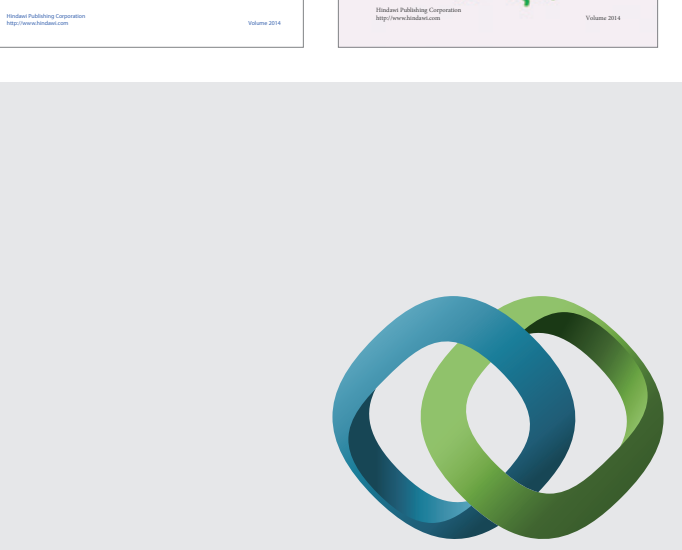

\section{Hindawi}

Submit your manuscripts at

http://www.hindawi.com
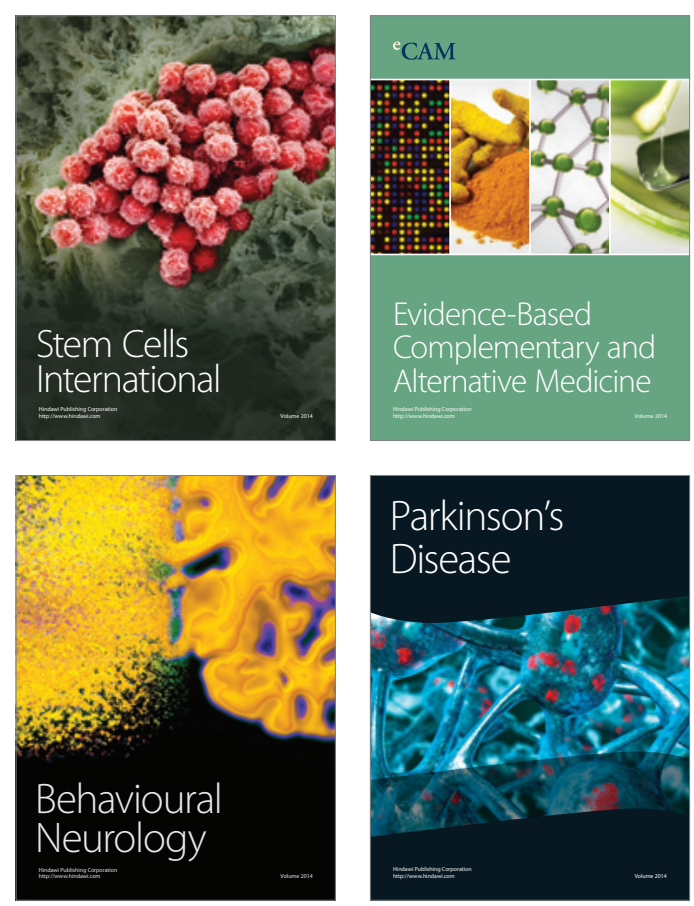

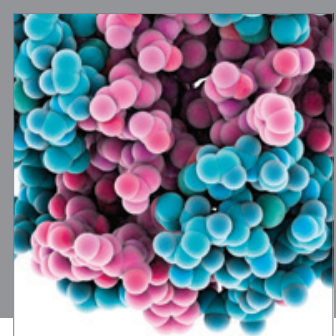

Journal of
Diabetes Research

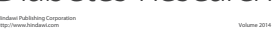

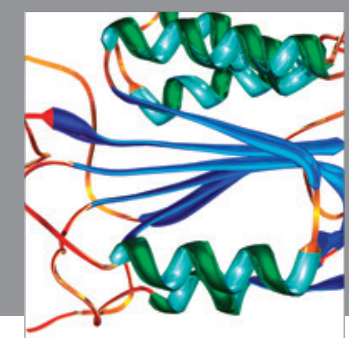

Disease Markers
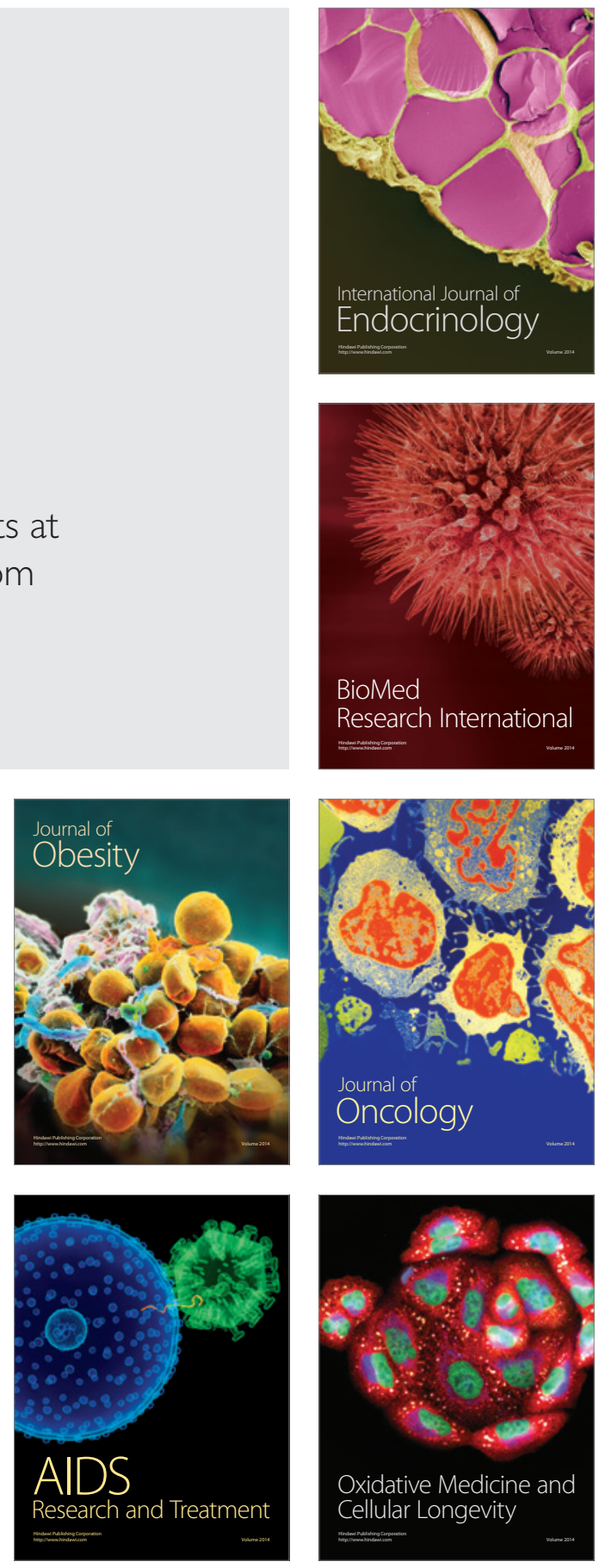